самостоятельность бюджетов, равенство бюджетных прав субъектов РФ, муниципальных образований, принцип сбалансированности бюджета и другие [14].

Таким образом, принципы финансового права играют важную роль в становлении и развитии финансового права, также они являются основополагающими идеями. Принципы финансового права учитывают изменения, которые происходят в правовой, экономической и политической жизни государства и общества.

Значение руководящих идей финансового права сложно переоценить, так как финансовое право не имеет кодифицированный акт, который регулировал бы всю систему финансового законодательства. Благодаря принципам финансовая деятельность государства приобретает системный, целенаправленный и структурированный характер.

$$
* * *
$$

1. Ровинский Е.А. Основные вопросы теории советского финансового права // изд. Госюриздат. М., 1960. 193 с.

2. Химичева Н.И. Финансовое права: Учебник. изд. Юристъ, М.: 2004. 749 с.

3. Карев Д.А. Критерии классификации правовых принципов: предметный, нормативный и функциональные подходы // Известия Саратовского университета. Новая серия. Серия: Экономика. Управление. Право.2018.С. Т. 18. № 3. С. 357-361.

4. Крохина Ю.А. Финансовое право: Учебное пособие для вузов. Юрайт-Издат, 2008. 429 с.

5. Запольский С.В. Методологические основы исследования принципов финансового права // Принципы финансового права. Материалы международной научно-практической конференции. Харьков, 19-20 апреля 2012 г. Харьков: Право, 2012. С. 98-99.

6. Пилипенко А.А. Принципы финансового права России и их нормативное закрепление // Автореферат М.; 2013. 27 c.

7. Нищимная С.А., Крупко Я.М., Доний Н.Е. Проблемы содержания общих принципов финансового права // Вестник Томского государственного университета. 2019. №444.

8. Козырин А.Н. Материалы лекции по финансовому праву. Режим доступа URL: https://wiselawyer.ru/ (дата обращения: 27.02.2021)

9. Шаков Е.Е. Финансовое право. 2008. Режим доступа URL: https://lawbook.online (дата обращения: 27.02.2021)

10. Налоговый кодекс РФ. Часть первая: от 31.07.1998 № 146-Ф3 : (ред. от 15.02.2016 N 32-Ф3, от 05.04.2016 N 101-Ф3, от 05.04.2016 N 102-Ф3, от 26.04.2016 N 110-Ф3, // Консультант Плюс. - Режим доступа URL: http://www.consultant.ru/ (дата обращения: 27.02.2021)

11. Шагиева P.B. Принципы финансовой деятельности. Режим доступа URL: https://justicemaker.ru (дата обращения: 27.02.2021)

12. Крохина Ю. А. Налоговое право России: Учебник для вузов. М.: Норма, 2004. - 720 с.

13. Винникова И. В. Банковский надзор в системе финансово-правового регулирования банковской деятельности в Российской Федерации: диссертация к. ю. н. 12.00.04 МГЮА. - М., 2015. - 208 с.

14. Бюджетный кодекс Российской Федерации от 31.07.1998 N 145-Ф3 (ред. от 28.11.2018) // Собрание законодательства РФ, 03.08.1998, N 31 // Консультант Плюс. - Режим доступа URL: http://www.consultant.ru/ (дата обращения: 27.02.2021)

\title{
Степанова Ж.А. \\ Вопросы совершенствования отношений в сфере разграничения предметов ведения и полномочий между республикой Марий Эл и Российской Федерацией
}

Марийский государственныцй университет (Россия, Йошкар-Ола)

doi: $10.18411 / s r-05-12-2021-28$

Аннотация

Статья посвящена правовым нормам, устанавливающим базовые начала разграничения предметов совместного ведения Российской Федерации и ее субъектов, как одному из элементов конституционно-правового статуса Республики Марий Эл, с целью определения перспектив их совершенствования. 
Ключевые слова: публичная власть, национально-территориальное образование, административно-территориальное образование, федерализм, законность, финансовое обеспечение, передача полномочий.

\section{Abstract}

The article is devoted to the legal norms establishing the basic principles of delimiting the subjects of joint jurisdiction of the Russian Federation and its subjects, as one of the elements of the constitutional and legal status of the Republic of Mari El, in order to determine the prospects for their improvement.

Keywords: public authority, national-territorial entity, administrative-territorial entity, federalism, legality, financial support, transfer of powers.

Разграничение предметов ведения и полномочий между Республикой Марий Эл и Российской Федерацией рассматриваются и обсуждаются, но вопросы совершенствования отношений в сфере разграничения предметов ведения и полномочий между Республикой Марий Эл и Российской Федерацией актуален до сих пор.

Тенденцией последних лет стала передача региональным органам государственной власти некоторых федеральных полномочий, находящихся ранее в сфере совместного ведения субъектов и федерального центра, при этом такая передача сопровождается необходимыми субвенциями из федерального бюджета. Кроме того, эти полномочия могут в дальнейшем передаваться на муниципальный уровень, что демонстрирует гибкий механизм перераспределения государственных полномочий [4, c. 234]. Это, в свою очередь, позволяет увеличить эффективность принятия управленческих решений и значительно сократить расходы бюджета на их исполнение, при этом имеет место строгий контроль со стороны федерального центра за реализацией этих полномочий региональными и муниципальными властями. Отметим, однако, что данный механизм позволяет усилить административную опеку над органами власти субъекта РФ со стороны федеральных органов. органы местного самоуправления в свою очередь, испытывают двойной контроль над исполнением переданных им полномочий как со стороны федеральных, так и региональных органов власти. Ряд экспертов считает, что такая передача полномочий и излишний контроль за их исполнением должно быть скорее исключением, чем правилом [2, с. 67].

Кроме того, осуществление таких полномочий на основе субвенций не способствует укреплению налогового потенциала РМЭ. Установленный механизм передачи осуществления полномочий органов власти вышестоящего территориального уровня органам власти нижестоящих территориальных уровней на практике приводит к доминированию целевых трансфертов в системе межбюджетных отношений, их дробности. При значительном объеме делегированных полномочий, сопровождаемом передачей большого количества субвенций, он не оставляет Республике Марий Эл финансовых возможностей для проведения собственной политики, реализации собственных целей. Отсутствие учета региональных особенностей и связанных с ними приоритетов, в свою очередь, снижает эффективность федеральных трансфертов, ведет к неэффективному расходованию бюджетных средств. Нельзя не учитывать также, что нормативы отчислений из федерального бюджета на осуществление передаваемых полномочий далеко не соразмерны тем расходам, которые затрачиваются на их реализацию. Поэтому большинство передаваемых полномочий являются затратными для субъектов Федерации, что экономически не стимулирует органы государственной власти субъектов Федерации к их эффективному исполнению [7, с. 9].

Таким образом, имеют место недостатки в подходе к разграничению между органами государственной власти разных уровней. По мнению некоторых авторов, идея совместного ведения федерального центра и регионов, закреплённая в Конституции 
Российской Федерации, предполагает совместное решение проблем по предметам совместного ведения и, в связи с этим думается, что разграничение по предметам совместного ведения нельзя возводить в абсолют, делая из неё мерило ценности федерализма. По их мнению, следует шире использовать возможности законодательных предложений со стороны субъектов с тем, чтобы обеспечить динамику развития российского законодательства в сфере разграничения полномочий между федеральным центром и регионами [5, с. 25].

Надо сказать, что такое опережающее законодательное регулирование вполне соответствует существующей конституционной модели, которая предполагает реализацию собственного правового регулирования субъекта РФ по предметам совместного ведения с Российской Федерацией до издания федеральных законов. Однако Конституционный суд Российской Федерации подчёркивает в своих решениях, что принятый в таком опережающем порядке региональный правовой акт должен соответствовать федеральному закону после его издания. Об этом говорят и нормы Федерального закона «Об общих принципах организации законодательных (представительных) и исполнительных органов государственной власти субъектов Российской Федерации» [1].

Кроме этого, совершенствованию отношений федерального центра и регионов в сфере разграничения полномочий служит развитие соглашений в системе исполнительной власти федеральных органов и органов субъекта РФ. В настоящее время подобные соглашения реализуются лишь в системе некоторых органов исполнительной власти: Минздрава России, МЧС России и некоторых других. Отметим, что практика развития таких соглашений сдерживается в определённой мере Федеральным Законом № 184-Ф3, в статье 26.8 которого говорится о том, что «соглашения заключаются в том случае, если осуществление некоторых полномочий невозможно возложить на органы государственной власти субъекта РФ» [1].

При повышении ответственности федеральных органов исполнительной власти за осуществление надлежащего контроля за реализацией федеральных полномочий, в том числе переданных субъектам Российской Федерации на основе соглашений, такой способ регулирования порядка реализации полномочий мог бы стать дополнительным эффективным инструментом в решении указанных вопросов [3, с. 52].

Другой проблемой, связанной с разграничением полномочий между регионами и федеральным центром, является создание единой системы законодательства, предусматривающей верховенство Федеральной Конституции, но учитывающей особенности субъекта РФ [6, с. 71]. В последнее время объём правового регулирования по некоторым предметам совместного ведения заметно сужен; это касается, в первую очередь, местного самоуправления, избирательного права, организации органов государственной власти РМЭ, правовое регулирование в которых в большей степени перешло на федеральный уровень. В связи с этим законодательство РМЭ вынуждена механически копировать нормы федерального законодательства, без учёта местных особенностей. В связи с этим необходимо находить более действенные правовые решения и механизмы достижения необходимого баланса интересов при реализации законотворчества по предметам совместного ведения Российской Федерации и Республики Марий Эл. Существует также определенный перекос в соотношении актов исполнительной и законодательной власти РМЭ в сторону увеличения значения и объёма подзаконных актов в сравнении с законами

Среди других тенденций развития регионального законодательства следует назвать увеличение числа бланкетных норм, в том числе связанных с установлением структурной связи между законодательством Республики Марий Эл и федеральным законодательством. Установление в региональном законодательстве норм, указывающих на федеральное законодательство, приводит к неотъемлемой зависимости законодательной базы РМЭ от законодательной базы федерального уровня, ведь, по 
сути, нормы, закрепленные в законодательстве РМЭ, не могут действовать отдельно от федеральных норм.

Таким образом, прямым отражением избранного подхода к разграничению предметов ведения и полномочий между федеральным центром и регионами является качество государственного управления как в масштабе федерации, так и составляющих его системах. Выработанные механизмы, принципы, способы и критерии разграничения полномочий и предметов ведения между Федерацией и ее субъектами указывают на законодательную модель регламентации разграничения полномочий, которая имеет центристский характер. Одним из эффективных способов оптимизации соотношения, распределения и разграничения предметов ведения и полномочий между Российской Федерацией и субъектами Российской Федерации видится принятие единого федерального конституционного закона, в котором, во-первых, необходимо предусмотреть порядок разработки и обязательного согласования проектов основных законов субъектов РФ (изменений, дополнений) с Федеральным Собранием Российской Федерации, во-вторых, отразить в нем рекомендации субъектам Федерации по созданию ими нормативно-правовой базы.

$$
* * *
$$

1. Федеральный закон от 06.10.1999 № 184-Ф3 (ред. от 11.06.2021) «Об общих принципах организации законодательных (представительных) и исполнительных органов государственной власти субъектов Российской Федерации» // Собрание законодательства РФ. - 1999. - № 42. - Ст. 5005.

2. Галеев, Н.Р. Влияние федеративного устройства на механизм российского государства / Н.Р. Галеев // Мир современной науки. - 2018. - № 3. - С. 65-69.

3. Дзидзоев, Р.М. Федерация как форма государственного устройства: конституционные иллюзии и реальность / Р.М. Дзидзоев // Конституционное и муниципальное право. - 2021. - № 4. - С. 50-53.

4. Евдокимова, Д.В. Разграничение предметов ведения и полномочий между Федерацией и ее субъектами: проблемы и пути их решения / Д.В. Евдокимова, А.О. Питиримова // Вопросы российской юстиции. - 2021. - № 13. - С. 228-237.

5. Каюров, Е.А. Некоторые аспекты повышения эффективности системы разграничения предметов ведения и полномочий между уровнями публичной власти в России / Е.А. Каюров // Законодательство и экономика. - 2020. - № 6. - С. 9-29.

6. Ковалев, Я.В. Проблемы разграничения предметов ведения и полномочий между федерацией и ее субъектами (на примере Российской Федерации) / Я.В. Ковалев // Актуальные проблемы правотворчества и правоприменительной деятельности в Российской Федерации. - 2019. - С. 68-71.

7. Харитонова, О.Н. Оптимизация модели разграничения предметов ведения и полномочий в РФ / О.Н. Харитонова, К.Д. Ванян, Н.Г. Донская // Черные дыры в Российском законодательстве. - 2018. - № 1. - C. 6-9.

\section{Сусликова К.С. \\ Международно-правовое регулирование права человека на достоверную информацию о состоянии окружающей среды}

Воронежский государственный университет (Россия, Воронеж)

doi: $10.18411 / s r-05-12-2021-29$

\section{Аннотация}

В данной статье автор анализирует международные документы, которые регулируют право человека на достоверную информацию о состоянии окружающей среды. Более подробно рассматривается Орхусская конвенция и причины, которые, по мнению автора, препятствуют российскому государству ратифицировать данный документ. В заключение приводятся авторские предложения, позволяющие привести российское законодательство, регулирующее право на достоверную информацию о состоянии окружающей среды, в соответствие с Орхусской конвенцией и другими международными документами. 